\title{
Brain and Spinal Cord Lesions in Encephalitozoonosis in Mink
}

\author{
By Inge Bjerkås \\ Department of Pathology, Norwegian College of Veterinary Medicine, \\ Oslo, Norway.
}

\begin{abstract}
Bjerkås, I.: Brain and spinal cord lesions in encephalitozoonosis in mink. Acta vet. scand. 1990, 31, 423-432. - Central nervous system lesions were studied by light microscopy in 43 farmed mink, aged 5 months to $21 / 2$ years, with spontaneous encephalitozoonosis and showing cataractous eye changes. Lesions were found in the brain and spinal cord of all animals examined but were generally mild and chronic. The lesions were consistent with those previously described in spontaneous encephalitozoonosis in other carnivores. Parasites in parasitophorous vacuoles and free or phagocytosed in necrotic and granulomatous lesions were demonstrated in animals aged 5 months to 1 year. The occurrence of arterial lesions of the polyarteritis nodosa type found in the youngest animals probably indicates fetal infection. In animals aged $11 / 2$ and $21 / 2$ years active lesions were usually lacking and the changes were characterized by arterial sclerosis, sometimes with aneurysmal formations, small perivascular lympho-plasmacytic cuffings and focal gliosis.
\end{abstract}

Encephalitozoon cuniculi; neuropathology; light microscopy.

\section{Introduction}

The intracellular, microsporidian parasite Encephalitozoon cuniculi (Nosema cuniculi), has for years been known as an important pathogen in farmed blue foxes (Alopex lagopus) in the Nordic countries (Nordstoga et al. 1972), while the mink (Mustela vison) has been regarded as resistant (Nordstoga et al. 1974). Encephalitozoonosis has previously been confirmed only in 1 member of the family Mustelidae, the Siberian polecat (Mustela eversmanni satunini) (Novilla et al. 1980).

During recent years, however, infection with E. cuniculi resulting in cataractous lenticular lesions and blindness has been recognized in several mink farms in the southwestern part of Norway (Bjerkås et al. in prep.). Neurological signs were noted in a few affected animals, a fact that might reflect less involvement of the brain and spinal cord compared with the condition in other carnivores. A pathomorphological study of brains and spinal cords were therefore performed in cases of spontaneous encephalitozoonosis in mink aged 5 months to $21 / 2$ years.

\section{Material and methods}

CNS material from 43 mink with spontaneous encephalitozoonosis, all suffering from cataract in one or both eyes, was studied by light microscopy. The animals were of different colour phases and of both sexes. They were divided into 4 groups based on age (5 months to $21 / 2$ years; Table 1 ). Normal E. cuniculi sero-negative animals aged 1 1/2-3 1/2 years were included as controls. Parasitic spores, which stained positively both with the modified Gram's method and the avidin-biotin-complex (ABC) method with antiserum raised against E.cuniculi 
were demonstrated in lens sections of all cases in groups I and II. In the other cases the etiological diagnosis was supported by positive antibody titre. All animals included in the present study, except for 4 cases in group I, had no antibody titres against plasmacytosis. Serological examination of antibodies against Toxoplasma gondii was performed on the cases of group II and was found to be negative. Further details concerning the serological examinations are given in another report (Bjerkås et al. in prep.).

Transverse sections from 6 different levels of all brains, fixed in $10 \%$ buffered formalin, were processed routinely for histologic examination. Additionally, sections were obtained from 4 levels of the spinal cord in 12 cases (groups I and II). In most cases the material was obtained within a few hours after euthanasia. All sections were stained with hematoxylin and eosin ( $\mathrm{H} \& \mathrm{E})$, and selected sections were also stained with elastin van Gieson, periodic acid Schiff (PAS). Wilder's silver stain, methyl green-pyronin, phosphothungstic acid hematoxylin (PTAH), luxol fast blue, Bodian's method, the cresyl fast violet method for Nissl's granules and the modified Gram's method (Petri 1969).

\section{Immunohistochemical studies}

Formalin-fixed, paraffin-embedded material was also used for immunohistochemical studies. The avidin-biotin-complex (ABC) method (HSU et al. 1981) was applied using an ABC kit ${ }^{\circledR}$ (Vector Laboratories, Burlingame, $\mathrm{Ca})$, according to a procedure described in a previous report (Bjerkås \& Landsverk 1986). Antiserum raised against $E$. cuniculi (Testman A/S, Uppsala, Sweden), neuron-specific enolase (NSE) and glial fibrillary acid protein (GFAP) (Daco Corporation, Santa Barbara, $\mathrm{Ca}$ ) was used as a primary antibody. In some sections the $\mathrm{ABC}$ procedure was also performed on previously stained decolorized sections (Milios \& Leong 1987).

\section{Results}

Gross lesions were not observed. Multifocal microscopic changes were found in all cases. Gram-positive, ovoid parasitic spores reacting with antiserum raised against $E$. cuniculi were always few, but were demonstrated in all animals of group I. The parasites occurred either in parasitophorous vacuoles (PV) in nervous tissue or arterial walls or as free and/or phagocytosed spores in necrotic and granulomatous lesions (Figs. 1-4). In animals of group II (aged 1 year), a single PV devoid of inflammatory reaction was found in 1 mink (Fig. 4), while phagocytosed parasitic material were also demonstrated in 2 additional cases. Parasites were not found in any of the animals in groups III and IV.

The PV observed in the nervous tissue were rounded and large, measuring up to about $80 \mu \mathrm{m}$ in diameter. However, the host cells were so distended and visible cytoplasm so scanty that their identity could usually not be determined. The PV found in arterial walls were of various sizes, mostly with an extended shape. They were confined to the medial layer and probably located in smooth muscle cells.

The lesions were generally mild and mostly chronic in all groups. Active lesions were usually associated with the presence of parasites or material reacting with antiserum raised against $E$. cuniculi. Lesions in the nervous tissue were mostly restricted to the grey matter, and the cerebral cortex and brain stem were most severely affected. Occasional focal necroses containing free and phagocytosed parasites occurred in all cases of group I. In addition, focal granulomatous lesions consisting of macrophages of epithelioid type, intermingled with neutrophils, 
Table 1. Case material. Age and sex of affected animals and normal controls.

\begin{tabular}{|c|c|c|c|}
\hline Group & Age & Number & Sex \\
\hline \multicolumn{4}{|c|}{ Case groups } \\
\hline I & $5-6$ months & 14 & $\begin{array}{l}5 \text { females, } 3 \text { males } \\
\text { (sex not recorded } \\
\text { in } 6 \text { cases) }\end{array}$ \\
\hline II & 1 year & 10 & 9 females, 1 male \\
\hline III & $11 / 2$ years & 8 & 6 females, 2 males \\
\hline IV & $21 / 2$ & 11 & 9 females, 2 males \\
\hline $\begin{array}{l}\text { Control } \\
\text { group }\end{array}$ & $11 / 2-31 / 2$ & 10 & 7 females, 3 males \\
\hline
\end{tabular}

lymphocytes and plasma cells were found. Phagocytosed spores and granular material reacting with antiserum against $E$.cuniculi could be demonstrated in most granulomas (Fig. 3). Focal hypercellular areas, consisting of fibrous astrocytes and microglial cells without clear phagocytic features were evident in all groups. Some sections also showed small accumulations of macrophages laden with hemosiderin and lipopigments.

The animals of group I exhibited active arterial lesions with medial necroses and granulomatous inflammation, particularly in the meninges (Fig. 5). Although the inflammatory reactions frequently involved all layers, PV were only demonstrated in the media. Considerable granulomatous formations with numerous lymphocytes and plasma cells occurred in the adventitial layer (Fig. 5). The arterial lesions were restricted to segments, and frequently only a part of the circumference was affected, resulting in eccentric, nodular thickenings. Inflammatory infiltrations associated with veins and capillaries usually appeared as perivascular cuffings.

In animals older than 1 year, necrotic or granulomatous lesions were infrequent both in arteries and nervous tissue. However, focal gliosis could be demonstrated by im- munostaining in all cases, using antiserum raised against GFAP, even when insignificant in ordinarily stained sections (Fig. 11). Areas with scarring and even cystic changes were occasionally seen. The lesions in the animals of group III were principally of the same type as those of group IV but perivascular lympho-plasmacytic infiltrations were less prominent in the latter. Thrombosis and haemorrhages were uncommon findings.

Arterial sclerosis was found in all groups but was the most marked change noted in groups III and IV, in which active vascular lesions were lacking. In sclerotic vessels there were areas with atrophy and fibrosis of tunica media and splitting or disappearance of the internal elastic lamina (Figs. 6-9). A moderate adventitial lymphocytic and plasma cell infiltration was often present even in the oldest cases. Some changed arterial segments had thickened walls because of intimal fibromuscular proliferation (Fig. 7), although most arteries were thinned, often exhibiting local, fusiform or saccular, aneurymal dilations (Figs. 8 and 9). Occasional vessels with a lumen that was almost occluded by a fibromuscular mass probably represented thrombosed, recanalized arteries. Meningeal vessels were usually more seriously affected than those of the nervous tissue. However, a few vessels exhibited marked 
perivascular fibrosis which was merging with the surrounding gliotic nervous tissue (Fig. 10). Significant vascular changes were not found in any of the controls.

\section{Discussion}

Our observations of mink with ocular encephalitozoonosis suggest that the brain and spinal cord are common target organs also in this species, despite infrequent neurological signs. As changes were generally sparse and focally distributed, the appearance of neurological signs may be rather accidental, depending on the significance of affected areas.

Although previous reports of the condition of spontaneous encephalitozoonosis of carnivores have mostly been based on cases of fulminating infections, the lesions described in the present groups I and II are principally compatible with those found in the blue fox (Nordstoga 1972, Nordstoga \& Westbye 1976, Bjerkås \& Nesland 1987, Bjergkås 1987), dog (van Dellen et al. 1978, Shadduck et al. 1978), cat (van Rensburg \& du Plessis 1971) and Siberian polecat (Novilla et al. 1980). In groups I and II the changes also comprised arterial lesions of the polyarteritis nodosa type, which probably depend on hypersensitivity reactions (Nordstoga \& Westbye 1976) and may be a particular feature of encephalitozoonosis in carnivores (Canning \& Lom 1986). Furthermore, the occurrence of polyarteritis nodosa may be indicative of foetal infection, as lesions of this type were not observed in experimental, post-foetal encephalitozoonosis either in blue foxes (Mohn \& Nordstoga 1982) or dogs (Szabo \& Shadduck 1987). The demonstration of parasites in active lesions even of 1 year old mink suggests that also congenitally infected animals can transmit the infection vertically to their offspring.

There is apparently no previous report on such late stages of CNS encephalitozoonosis as studied in the present groups III and IV. The almost total lack of active lesions in animals of these groups may indicate that the parasites were eradicated, although the existence of persistent parasitophorous vacuoles probably cannot be discounted (Bjerkås \& Nesland 1987).

Studies in encephalitozoonosis of the blue fox (Bjerkås 1987) have suggested that the

Figure 1. Parasitophorous vacuoles (arrows) in medial layer of a meningeal artery. There is a marked mononuclear adventitial inflammation. $\mathrm{H} \& \mathrm{E} . \times 680$.

Figure 2. The same section and view as shown in Fig. 1, restained with antiserum raised against E. cuniculi. Positively reacting parasites are indicated by arrows. $\mathrm{ABC}$ procedure, counterstained with hematoxylin. $\times 680$.

Figure 3. Granuloma with central necrosis (N). Numerous, mostly phagocytosed, parasitic structures (arrows) exhibit immunoreactivity with antiserum raised against E.cuniculi. ABC procedure, counterstained with hematoxylin. $\times 680$.

Figure 4. Large parasitophorous vacuole showing immunoreactivity with antiserum raised against $E$. $c u$ nuculi. Cerebral cortex. ABC procedure. $\times 680$.

Figure 5. Lesions of polyarteritis nodosa type in meningeal artery. A necrotic area $(N)$ involves the whole thickness of the medial layer. Note nodular adventitial proliferation (A). H \& E. $\times 280$.

Figure 6 . Chronically changed, small meningeal artery. In the area which is indicated by arrows there is total fibrous transformation of the wall, with loss of the elastic and smooth muscular elements. Elastin van Gieson. $\times 430$. 


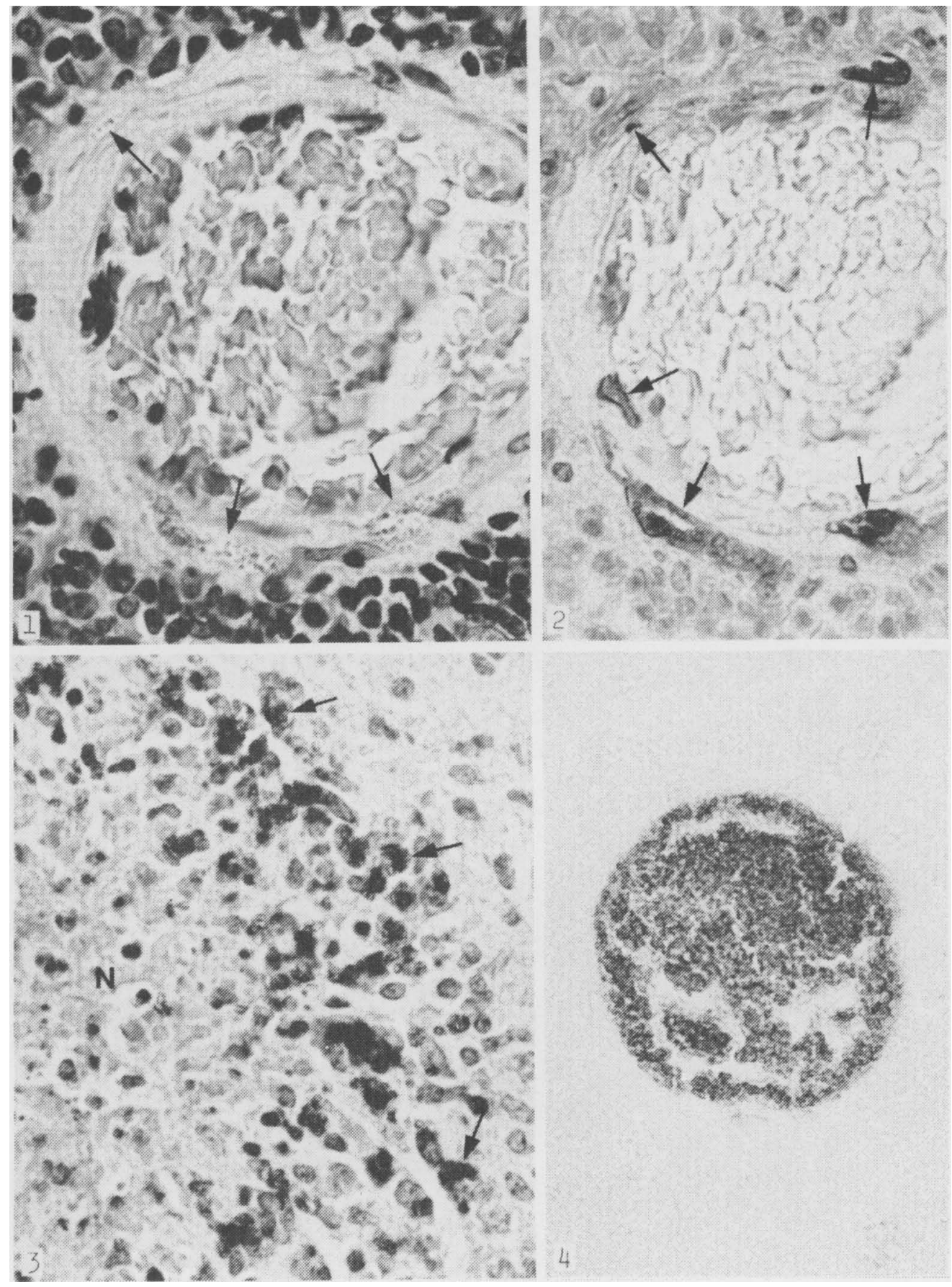




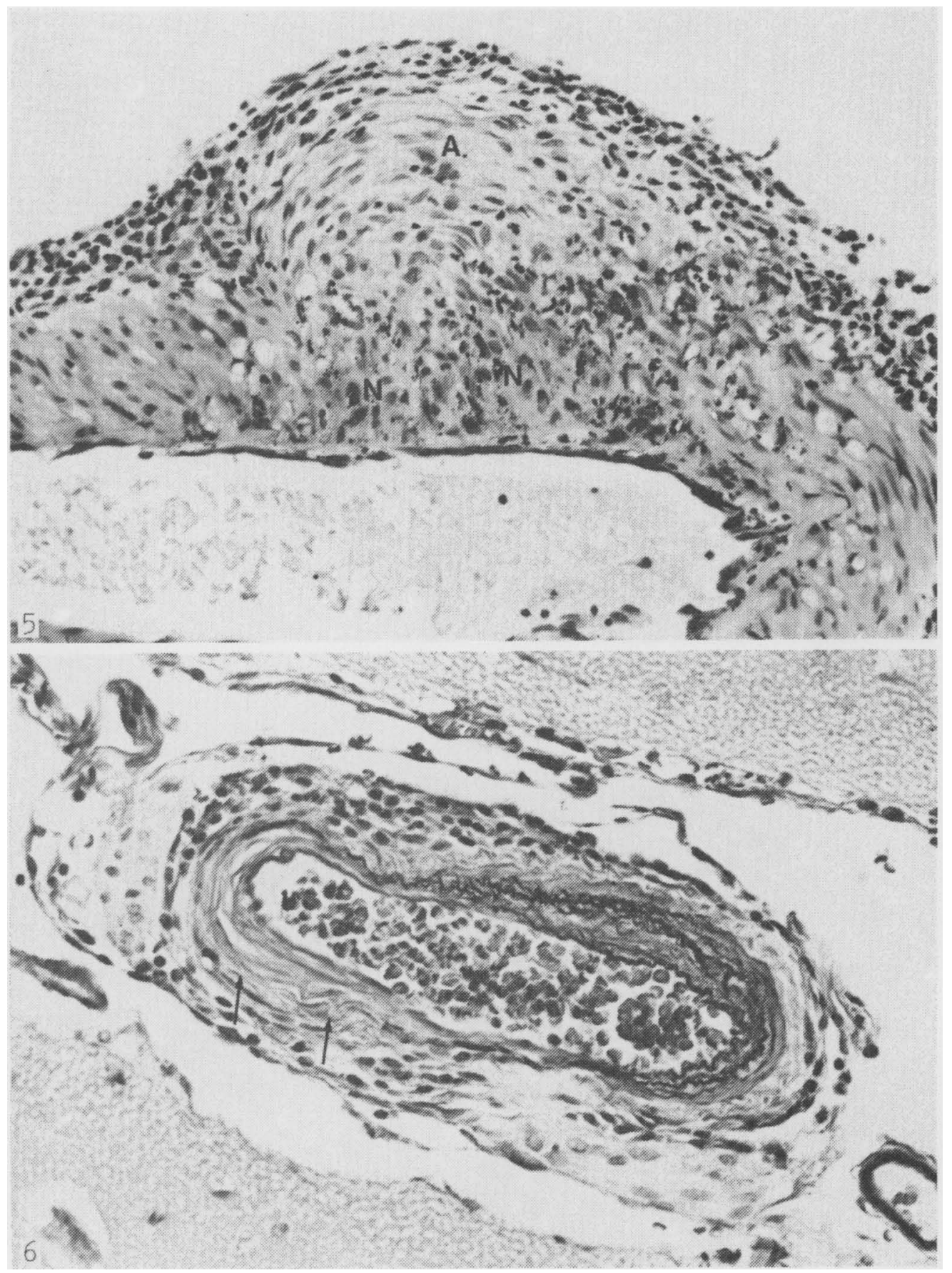




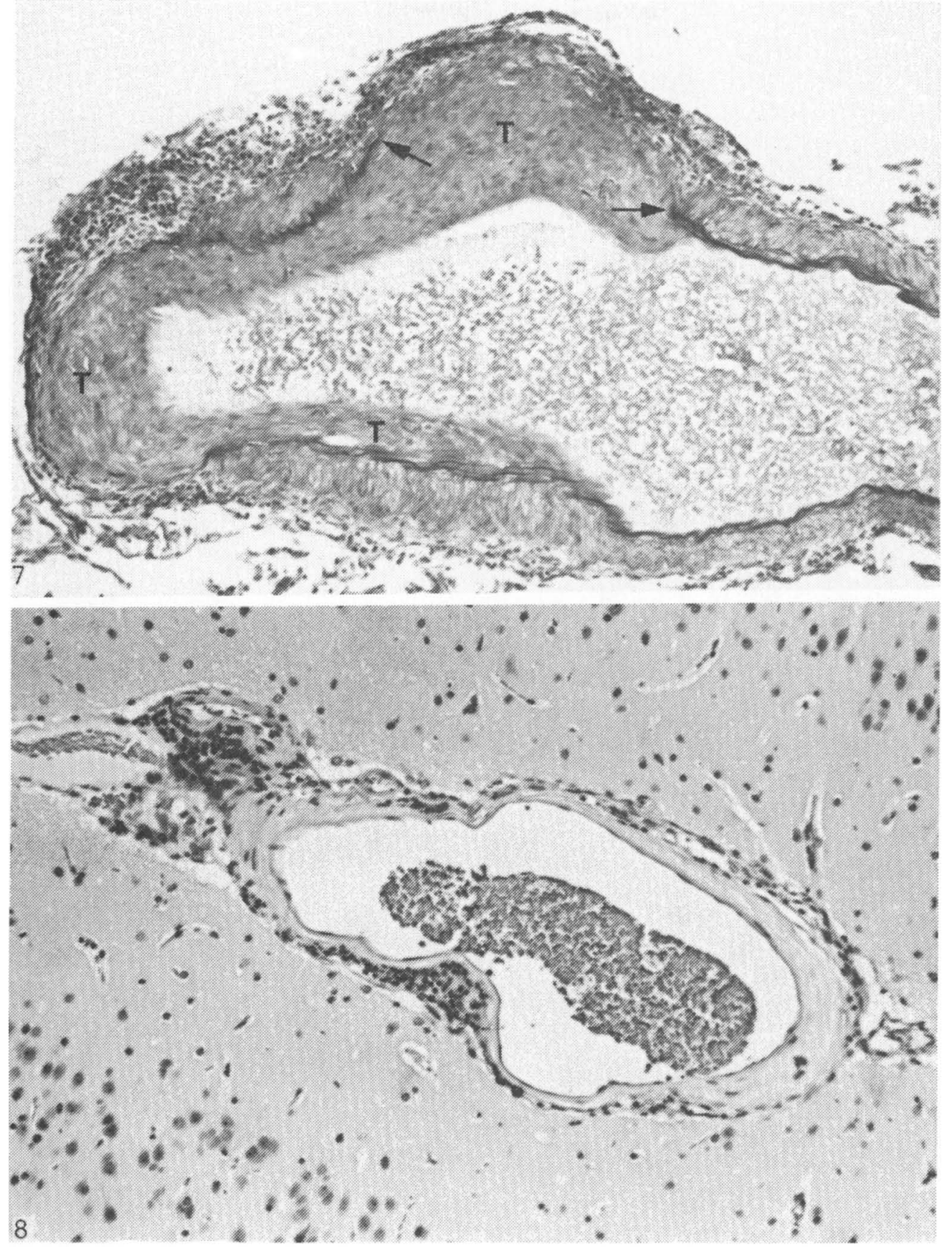




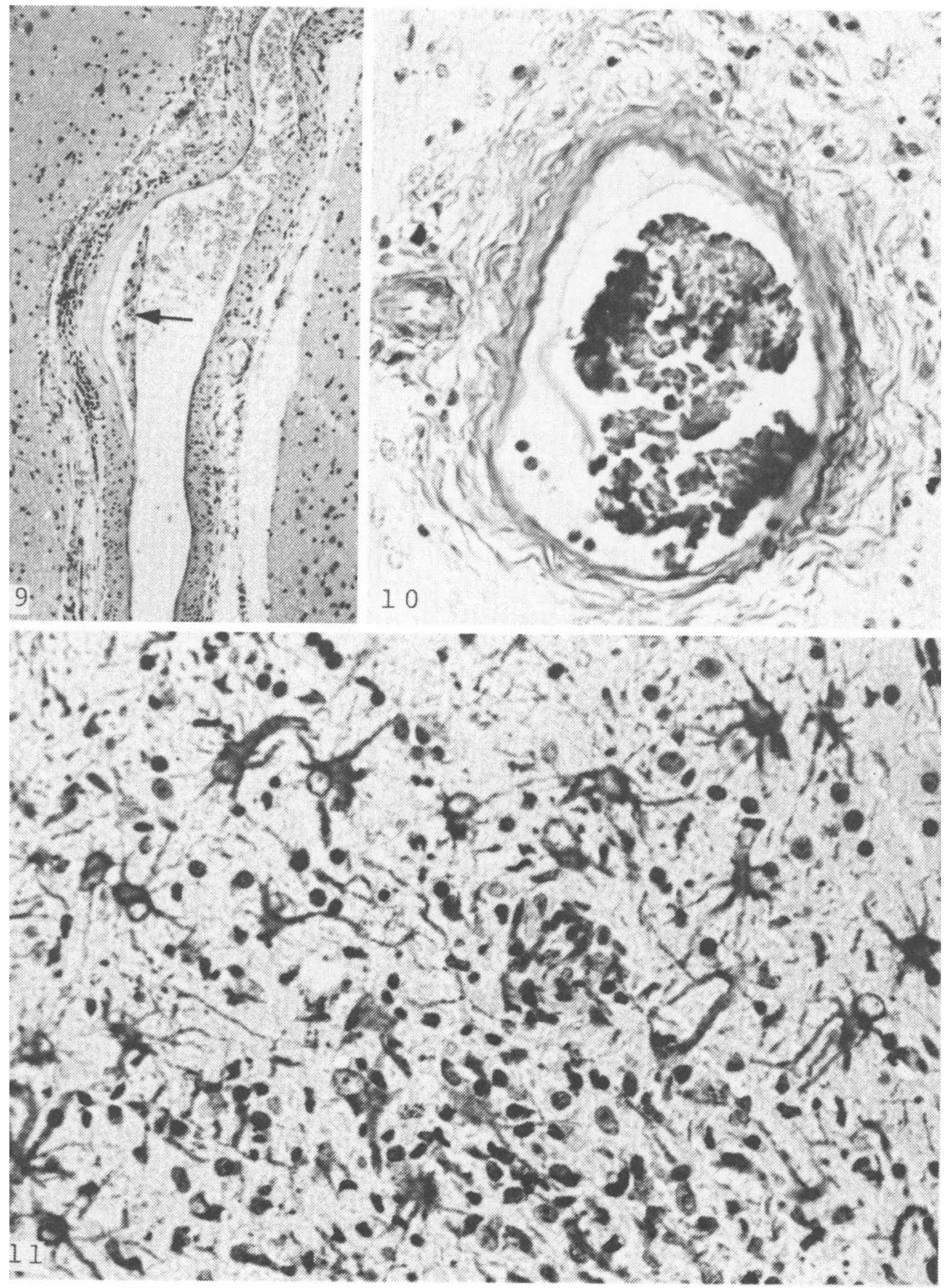


arterial lesions are due primarily to parasitism of medial smooth muscular cells and probable subsequent hypersensitivity reactions, resulting in local necroses, a fact that can explain the development of medial atrophy and aneurysmal dilations in sclerotic arteries of animals in the present groups III and IV (Buja 1987). Arnesen \& Nordstoga (1977) also reported aneurysmal formations in acutely changed arteries in fulminating encephalitozoonosis of the blue fox. Vascular rupture resulting in haemorrhage in the subarachnoidal space and ventricles is a common complication in the blue fox, particularly in animals younger than 2 months of age (Mohn 1982).

Lesions similar to polyarteritis nodosa have also been noted in plasmacytosis, a common viral infection in farmed mink (Henson \& Crawford 1974). This may be the most relevant differential diagnosis, but changes due to this infection can probably be ruled out in the great majority of the present cases, as antibodies against the plasmacytosis agent occurred only in 4 animals of group I. Furthermore, the outstanding arterial lesions make the present encephalitozoan infection distinctive from other known infections with CNS involvement. Arteriosclerosis of noninfectious origin is probably not common during the relatively short life-span of the farmed mink. The lack of arterial lesions in the controls, aged 1 1/2-3 1/2 years, supports this assumption.

\section{References}

Arnesen $K$, Nordstoga $K$ : Ocular encephalitozoonosis (Nosematosis) in blue foxes. Polyartertis nodosa and cataract. Acta Ophthalmol. $1977,55,641-651$.

Bjerkås I: Brain and spinal cord lesions in encephalitozoonosis in blue foxes. Transmission and scanning electron microscopic studies. Acta Pathol. Microbiol. Immunol. Scand. Sect. A 1987, 95, 269-279.

Bjerkås I, Landsverk T: Identification of Toxoplasma gondii and Encephalitozoon cuniculi by immunoperoxidase techniques and electron microscopy, in stored, formalin-fixed, paraffin-embedded tissue. Acta vet. scand. 1986, 27, 11-22.

Bjerkås I, Nesland JM: Brain and spinal cord - lesions in encephalitozoonosis in the blue fox. Acta vet. scand. 1987, 28, 15-22.

Bjerkås I, Nordstoga K, Nicolaissen B, Loftsgaard $G$ : Encephalitozoonosis in the farmed mink. In prep.

Bula LM: The vascular system. In: Basic Pathology (Eds. Robbins SL, Kumar V). WB Saunders Company, Philadelphia, London, Toronto, Sidney, Tokyo, Hong Kong, 1987, pp. 553 $-596$.

Canning EU, Lom J: The Microsporidia of Vertebrates. Academic Press. London, Orlando, San Diego, New York, Austin, Montreal, Sidney, Tokyo, Toronto 1986, pp. 189-241.

Figure 7. Chronically changed basal artery with marked fibromuscular, intimal proliferation $(T)$. In the area which is located between the arrows both the intimal elastic membrane and the medial layer are lost. Elastin van Gieson. $\times 170$.

Figure 8. Meningeal artery showing fibrous change of the wall with saccular attenuations. H \& E. $\times 170$.

Figure 9. Longitudinal section of a meningeal artery with aneurysmal dilation of an area with fibrous change. Note subendothelial aggregate of macrophages (arrow). H \& E. $\times 110$.

Figure 10. Perivascular fibrosis in grey matter of diencephalon. Elastin van Gieson. $\times 430$.

Figure 11. Hypercellular area of cerebral grey matter with reactive astrocytes, showing immunoreactivity with antiserum raised against glial fibrillary acid protein. ABC procedure, counterstained with hematoxylin. $\times 430$. 
Henson JB, Crawford TB: The pathogenesis of virus-induced arterial disease. - Aleutian disease and equine viral arteritis. Adv. Cardiol. 1974, 13, 183-191.

Hsu S-M, Raine L, Fanger $H$ : A comparative study of the peroxidase-antiperoxidase method and an avidin-biotin complex method for studying polypeptide hormones with radioimmunoassay antibodies. Amer. J. clin. Pathol. 1981, 75, 734-738.

Milios J. Leong $A S$ - $Y$ : The application of the avidin-biotin technique to previously stained histological sections. Stain Technol. 1987, 62, 411-416.

Mohn SF: Experimental encephalitozoonosis in the blue fox. Clinical and serological examinations of affected pups. Acta vet. scand. 1982, 23, 503-514.

Mohn SF, Nordstoga K: Experimental encephalitozoonosis in the blue fox. Neonatal exposure to the parasite. Acta vet. scand. 1982, 23, 344-360.

Nordstoga $K$ : Nosematosis in blue foxes. Nord. Vet. Med. 1972, 24, 21-24.

Nordstoga K, Mohn SF, Loftsgaard G: Nosematose hos blårev. (Nosematosis in blue foxes). Proc. 12th Nord. Vet. Congr., Reykjavik 1974, 183-186.

Nordstoga $K$, Westbye $K$ : Polyarteritis nodosa associated with nosematosis in blue foxes. Acta Pathol. Microbiol. Scand. Sect. A 1976, 84, 291-296.

Novilla $M N$, Carpenter $J W$, Kwapien $R$ : Dual infections of Siberian polecats with Encephalitozoon cuniculi and Hepatozoon mustelis n.sp. In: Comparative Pathology of Zoo Animals. Eds. Montali RJ \& Migaki G. Proc. Symp. Nat. Zool. Park., Smithsonian Institution 1980, p. 353-363.

Petri M: Studies on Nosema cuniculi found in transplantable ascites tumours with a survey of microsporidiosis in mammals. Acta Pathol. Microbiol. Scand. Suppl. 204, 1969.

Shadduck $J A$, Bendele $R$, Robinson GT: Isolation of the causative organism of canine encephalitozoonosis. Vet. Pathol. 1978, 15, 449460.

Szabo JR, Shadduck JA: Experimental encephalitozoonosis in neonatal dogs. Vet. Pathol. 1987, 24, 99-108.

van Dellen AF, Botha WS, Boomker J, Warnes $W E J$ : Light and electron microscopical studies on canine encephalitozoonosis: Cerebral vasculitis. Onderstepoort J. vet. Res. 1978, 45, 165-186.

van Rensburg IBJ, du Plessis JL: Nosematosis in a cat: A case report. J. S. Afr. vet. med. Assoc. 1971, 42, 327-331.

\begin{abstract}
Sammendrag
Patoanatomiske forandringer $i$ hjerne og ryggmarg ved encephalitozoonose hos mink.

De patoanatomiske forandringene i sentralnervesystemet ved spontan encephalitozoonose ble undersøkt hos 43 mink. Dyrene som var i alderen 5 mdr til $21 / 2$ år, hadde alle katarakt. Forandringer ble påvist $\mathrm{i}$ hjerne og ryggmarg hos alle de undersøkte dyrene, men var generelt moderate og for det meste av kronisk type. Forandringene tilsvarte i store trekk de som er beskrevet tidligere ved spontan encephalitozoonose hos andre rovdyr. $\mathrm{Pa}$ rasitter ble påvist hos mink i alderen $5 \mathrm{mdr}$ til 1 år og forekom enten i parasittofore vakuoler eller fritt eller fagocyttert i nekrotiske og granulomatøse foci. Forekomst av arterieforandringer i form af polyarteritis nodosa tyder på føtal infeksjon. Aktive prosesser manglet for det meste hos dyrene i aldersgruppen 1 1/2-2 1/2 år og forandringene var her karakterisert av arteriosklerose med aneurismedannelser, små perivaskulære lymfo-plasmacyttære infiltrater og fokal gliose.
\end{abstract}

(Received October 3, 1989; accepted January 17, 1990).

Reprints may be requested from: I. Bjerkås, Department of Anatomy, Norwegian College of Veterinary Medicine, P. O. Box 8146 Dep., N-0033 Oslo 1, Norway. 